\title{
GATA2 wt Allele
}

National Cancer Institute

\section{Source}

National Cancer Institute. GATA2 wt Allele. NCI Thesaurus. Code C97553.

Human GATA2 wild-type allele is located in the vicinity of 3q21.3 and is approximately 14 $\mathrm{kb}$ in length. This allele, which encodes endothelial transcription factor GATA-2 protein, plays a role in both transcriptional regulation and DNA binding. Mutation or aberrant expression of the gene is associated with myelodysplasic syndrome, chronic myeloid leukemia and aplastic anemia. 